\title{
Project management office in central banks: relationship between the practice of projects and economic stability
}

Escritório de gerenciamento de projetos em bancos centrais: relação entre prática de projetos e estabilidade econômica

\author{
Juliana Rigassi ${ }^{1 *}$; Carlos Roberto Campos $^{2}$
}

${ }^{1 *}$ Bachelor of Economics with emphasis on International Trade - Am Pfisterhölzli 46, 8606 - Greifensee - Switzerland. <jrigassi@outlook.com>

${ }^{2}$ Escola Superior de Agricultura "Luiz de Queiroz" [ESALQ/USP]; Associate Professor and Specialist in Project Management; Av. Pádua Dias 11, 13418-900, Piracicaba, SP - Brazil.

\begin{abstract}
Projects are frequently used as a means to directly or indirectly achieving the goals of an organization's strategic plan, and the Project Management Office [PMO] is responsible for standardizing the governance processes to achieve those objectives. When it comes to independent federal agencies, such as Central Banks, their strategic objectives have a relevant impact on economic stability and, consequently, on the lives of millions of people. In this study, the best practices of the PMOs of four Central Banks were examined. The question in the study addressed the manner in which the practice of projects can be used as a tool for achieving economic stability. Qualitative methods were used to examine the question by means of a structured questionnaire applied to project professionals of these institutions, and analysis of data available in case studies was also conducted. It was noted that Central Banks increasingly seek to improve the practices of their Project Management Offices, becoming a center of reference for best practices in PMOs obtaining relevant recognition, either for the maturity of their projects, receiving the title of best PMOs in the country, or even being nominated for PMO of the year on a global level (Project Management Award), the highest award in the project management category.
\end{abstract}

Keywords: independent federal agencies, project maturity, macroeconomics

\section{Resumo}

Projetos frequentemente são utilizados como um meio de direta ou indiretamente alcançar os objetivos do plano estratégico de uma organização, sendo o Escritório de Gerenciamento de Projetos [EGP] responsável por padronizar os processos de governança de forma a atingir tais objetivos. Se tratando de uma empresa de autarquia federal como os Bancos Centrais, seus objetivos estratégicos têm um impacto relevante na estabilidade econômica e, consequentemente, na vida de milhões de pessoas. Nesta pesquisa, foram investigadas as melhores práticas dos EGPs de quatro Bancos Centrais. A questão da pesquisa tratou de como as práticas de projetos podem servir de ferramenta para se alcançar a estabilidade econômica. Empregou-se métodos qualitativos para investigar a questão por meio de questionário estruturado aplicado aos profissionais de projetos de tais instituições, e análise de dados disponíveis em estudos de caso. Notou-se que os Bancos Centrais buscam cada vez mais aprimorar as práticas de seus Escritórios de Gestão de Projetos, tornando-se centro de referência de melhores práticas em EGPs obtendo relevante reconhecimento, seja pela maturidade de projetos, recebendo títulos de melhores EGPs nacionais, ou até mesmo sendo nomeados para EGP do ano em âmbito global (Project Management Award), a premiação máxima da categoria de gerenciamento de projetos.

Palavras-chave: autarquias federais, maturidade de projetos, macroeconomia

\section{Introduction}

Projectmanagementhas been carried out formillennia. However, its recognition through the propagation of the "Project Management" nomenclature occurred in 1950, and the emergence of the first structured knowledge tools took place in the 19th century, during the Industrial Revolution. In the post-war period, projects underwent a process of complexification, especially with the US Department of Defense's methodology of network visualization and schedule progress measurement, through mechanical engineer Henry Gantt (Barcaui, 2012). Large-scale projects that require planning, organization, and, in general, a knowledge of project management, have been developed since the earliest days of humanity, such as the Ziggurats of Mesopotamia (400-300 BCE), the Pyramids of Giza (2550 BCE), the Coliseum (68-78 CE), and Noah's Ark (2348 BCE) (Chiu, 2010). Where once the focus was the enrichment of cultural heritage, currently there are numerous objectives that cover legal, strategic, economic-financial, 
market, technological, and other requirements. This magnitude requires multifaceted management with various fields of knowledge, making it necessary to create an organizational structure that standardizes the governance processes related to projects, facilitating the sharing of resources, methodologies, tools, and techniques (PMI, 2013). In other words, implementing a Project Management Office [PMO]. It should be noted that the most widely known term in international literature is Project Management Office [PMO], but it may have variations such as: Corporate Project/Program Management Office [CPMO], Project Management Center of Excellence [PMcoE], Project Support Office [PSO], Project Office [PO] (Bolles, 2002).

The more complex the core business of a company is, the greater the process interface and the demand for a structured PMO. This structure is the case analyzed in Central Banks [CBs], independent federal agencies that, on a daily basis, develop projects that affect the economy, influencing savings, purchasing power, jobs and, consequently, people's lives. According to Keynes (1973), the government must actively manage the economy in order to control economic cycles, popularly known as economic crises, phenomena that cause profound social changes. The role of the PMO is grounded in this process of constant social change since, by definition, the PMO is an agent of change (PMI, 2017). Throughout history, we have recorded many economic crises in developing countries, such as Brazil, which in the 1990s was affected by an inflationary and monetary crisis. There is also a record of crises in developed countries, such as the great depression that shook the New York stock exchange in the 1930s.

From the 1990s onwards, there was a need for a specific department at Central Banks which, together with government agencies, would control all work fronts with a view to stabilizing the economy, mainly in response to crises. In 1997, a PMO was officially conceived in its first outlines. The use of project management practices began in independent federal agencies as a tool for development and economic stabilization (Barcaui, 2012). There are cases that indicate recognition, by Central Banks, of the importance of the PMO and the efficiency and effectiveness of the performance of projects when they are monitored with governance techniques. In 1998, due to a major crisis in the Brazilian banking system, the "Programa de Assistência Técnica" [PROAT], or Technical Assistance Program, was created between the Central Bank of Brazil and the World Bank, implementing a series of standards to consolidate a PMO. The World Bank injected capital for the implementation of the project, which was divided into several phases: implementation, program management, and maturity. Then, in 2014, the PMO of the Central Bank of Brazil
[PMO-CBB] reached a maturity level of 4.2 with the Prado-MMGP technique and received, in the same year, the title of "PMO of the Year - domestic level" and today is a reference for good practices in Project Management (Caracas and Cota, 2014). Another success was the nomination of the PMO of the Central Bank of the Dominican Republic [PMO-CBDR] for one of the most significant awards in in the field of projects: the PMI Award, competing in the "2014 PMO of the year - international level" category. In 2007, the monetary council of the $\mathrm{CB}$ approved the implementation of a PMO to collaborate with the institutional strategic objectives for the period of 2006-2009, and performance monitoring identified an improved effectiveness of $97 \%$ in implementation of strategic initiatives and improvement of the main economic indicators (PMI, 2014).

Based on the scope of the PMOs, the objective of this proposal is to show that project management is relevant as a mechanism of economic stabilization and development by structuring and standardizing governance processes and good practices, in addition to having the flexibility essential to the different stages and strategies of Central Banks. In this respect, it has the potential to corroborate the fulfillment of the mission of these independent federal agencies to ensure the stability of the currency's purchasing power in an efficient solid financial system (Aguiar et al., 2015).

\section{Materials and Methods}

To better understand the subject presented, a descriptive survey was conducted through a structured questionnaire. Together with this, additional data was taken into account, such as case studies and official documents provided by the surveyed population. The main objective of the preference for this research methodology was to describe the characteristics of a certain population for future relation with other variables (Diehl and Tatim, 2004).

\section{Location of the Study}

Eleven Central Banks, located in Brazil, France, Dominican Republic, Switzerland, England, Portugal, Italy, Germany, Belgium, Ireland, and also the European Central Bank were considered in the Study, of which only the first four were effectively studied, since the other refused the invitation to participate and to provide data. According to Lastra (2000), Central Banks have undergone a major change in the last decade. Where once only the Federal Reserve System, the German Central Bank, and the Swiss National Bank had independence, today, many of these independent federal agencies understand that detachment from the governmental sphere provides an institutional basis for the credibility 
of a monetary policy committed to the stability of prices and economic development, despite being intrinsically related to the government of their country and to the legislature.

\section{Sample researched}

The Central Banks were selected for being the institution responsible for steering the secondary variable adopted in the study: economic stability. It is worth noting that the primary variable and subject of this study are the project management offices of these institutions. Thus, the assumption adopted was that $100 \%$ of those interviewed had a PMO.

The criterion for selecting the interviewees was based on reference indicators and/or excellence in project management practices. The seven $\mathrm{CBs}$ that were invited bur are not participants of the survey were selected for their relevance and pertinence to the subject. However, due to their refusal, which resulted in a lack of depth, the specific motives of these CBs will not be detailed. Regarding the participants, Switzerland made world headlines in project management in June 2016 by completing the Gottard-"Basistunnel" Project, the world's longest railway tunnel at $57 \mathrm{~km}$ through the 115 $\mathrm{km}$ of tracks in large tunnels that cut through the Swiss Alps. After 17 years and roughly 11 million euros, despite the complexity and size, the scope was exactly what was delivered, respecting the deadline, budget, and funds (Project Blue Magazin, 2016). That said, Switzerland, known for its rigorous quality standards, became one of the ideal candidates for this study.

Maturity and recognition of the PMO of the Central Bank were taken into account when fitting Brazil into the study. In 2016, Brazil registered 17,622 Project Management Professionals [PMP $\AA$ certification] and is the Latin American country with the highest number of certified professionals (PMTech, 2016). In 2014, during the 9th Project Management Congress in Brazil, the PMO of the Central Bank of Brazil received the PMO of the year award for the respective year, becoming a center of reference on a level of project maturity. Every month, two to three organizations are invited to learn about the processes practiced by this PMO, so as to assimilate the good practices of this center of excellence (Aguiar et al., 2015).

The criterion applied to the selection of the Dominican Republic was also its recognized excellence in the surveyed segment. In 2007, faced with a scenario of economic chaos, the Country approved the implementation of a Portfolio Management Office to ensure that the strategic planning targets for 2006-2009 were met. In the seven years after its implementation, there were 345 projects, of which $76 \%$ were successfully completed. In 2014, the PMO was one of the finalists for the "PMI Award" as PMO of the year on an international level, indeed a center of reference in project management practices in central banks (PMI, 2014).

France was selected because it is a very important member of the European Union, and in terms of project practices, it has the largest PMO among those interviewed, comprising a cross-functional team of 3050 people.

\section{Procedure}

Since the media relations departments of Central Banks are in some cases responsible for approving any information to be disclosed and, consequently, published about the institution, these have been defined as the channel for access to the independent federal agencies. This strategy was aimed at directing the demand to the corresponding department. After validation and submission of the advisory services, an email was sent to each person responsible for the PMO (directive and managerial level) containing an explanatory text about the study, official data from the university, professional profile of the interviewer, and, finally, a link to website where the interviewee can fill out the survey. The survey was available for a period of 85 days, i.e., from March 27 to June 19, 2017, and is considered a long period for providing interviewees at the top of the hierarchy the possibility of reconciling this request with their busy schedules. The procedure also took into account that some answers could compromise the character of the institution, since they represent the views of individual respondents, subject to their own perceptions, as active participants in the $\mathrm{CB}$, based on their professional, educational, and personal backgrounds. Therefore, a comparative validation with official data published on behalf of these institutions is also included.

\section{Instrument}

Regarding the tool used, due to security and credibility issues, a Typeform (web-based survey platform) license was purchased for collecting and sharing information in an interactive, simple, and intuitive manner. This license also provided access to additional resources such as real-time data analysis dashboard, flexibility in response options (multiple-choice questions, rating, long/short answers, custom layout, among others).

To develop the questionnaire, English was used as the standard language of communication among the interviewees, since the questionnaire was directed to four different countries whose official languages are Spanish, German, Portuguese, and French. The questionnaire consists of 14 questions, three open-ended and 11 closed-ended, developed in light of the PMO value ring methodology, a tool developed with the participation of PMO leaders with cases of success, as well as high levels 
of maturity, with the goal of developing a solution to support the creation, review, and operation of a PMO, in addition to focusing on generating effective value for the organizations. The PMI Northern Italy Chapter PMO diagnostic questionnaire (2017) was also used as a basis. The questionnaire format is presented in Table 1, below.

Table 1. Survey questionnaire format

\begin{tabular}{ccc}
\hline Type & Classification & Amount \\
\hline \multirow{2}{*}{ Open questions } & 70 characters $\left(^{*}\right)$ & 1 \\
& 999 characters $\left(^{* *}\right)$ & 2 \\
Closed questions & Yes or No $\left(^{*}\right)$ & 1 \\
& Multiple choice $\left(^{*}\right)$ & 10 \\
\hline Total of questions & & 14
\end{tabular}

* Mandatory response; ** Optional response

\section{Data collected}

Each question was associated with PMO measurement requirements, following the theoretical basis explained individually in the "results and discussion" field, organized in analysis blocks, as follows: Structure: Country; confirmation of the existence of a PMO; project management methodology; lifespan and size of a PMO; Profile: Type of projects managed and the PMO's level of activity; Implementation: Motivations for implementing the PMO; difficulties in the initial processes; team that carried out the implementation and success factors; Post-implementation results: Postimplementation benefits (in the scope of projects, as well as economic, better explained in the "macroeconomic stability concept" field); cases and challenges.

\section{Taxonomy for the tabulation and interpretation of data}

Because it is a qualitative questionnaire, and therefore requiring the interpretation on non-numerical data and a personalized individual analysis for each question, the tool used in the survey allowed for a general report containing the responses, consolidated and summarized by interviewee. The data collected with the time and performance indicators of the PMOs were interpreted and analyzed along with economic indexes, previously selected, based on economic reasoning.

\section{Concept of the project management office}

For Kerzner (2013), the PMOs are organizations developed to provide the necessary support for Project Managers to fulfill their duties and obligations, mediating the issues between the project team and functional managers. As a structure that standardizes processes, the PMOs facilitate the sharing of resources, methodologies, tools, and techniques in order to organize management and enable the development of routines.
According to PMI statistics (PMTech, 2016), it is estimated that approximately $1 / 5$ of the world's GDP is allocated to projects and, between 2008 and 2016, there was a $172 \%$ increase in certified professionals (PMP $\AA$ ), proving Carneiro's (2010) claim that the PMO is a global phenomenon that has reached public, private, and third sector organizational structures. Nonetheless, their roles and responsibilities are the subject of a theoretical clash, but as Hallows (2002) defines it, the way PMOs are structured and their duties vary from company to company, especially in the governmental and federal spheres, defined by Crawford and Helm (2009), as a multifaceted sphere and complex, characterized by uncertainty, ambiguity, and stakeholder management issues.

Therefore, it follow the methodological analysis in the view of macroactivities of the respective PMOs of the Central Banks, each compatible with their phase of life (implementation, consolidation, or maturation), as well as their level of activity (control, support, or directive).

\section{Concept of macroeconomic stability}

In order to measure the progress and benefits generated by the implementation of PMOs in Central Banks, especially on the impact of macroeconomic stability, the timeframe for PMO implementation ( $t$ ) was analyzed, in detriment to the economic indicators, which measure the economic movement of the countries studied in US dollars (\$) and percentage change (\%). The intention of the economic measurement of the countries is not defined as equivalence, since there are developed and developing countries taking part in the same study, so each economic impact was analyzed to avoid skewing the results.

The economic measurement techniques began in 1670 with English scientist William Petty (McCormick, 2009). Although his calculations were considered controversial in the theoretical current, his basic ideas evolved into what we understand today as economic indicators. Today, the International Monetary Fund $[\mathrm{IMF}]$ is an organization comprising 188 countries, which promotes global monetary cooperation, secure financial stability, and facilitates international trade in order to promote sustainable economic growth and poverty reduction throughout the world. The statistical data of this study was obtained through the following sources: Gross Domestic Product [GDP]: the total amount of goods and services exchange for money in a country, in a given period, at current prices; Purchasing Power Parity [PPP] between two countries: is the rate at which the currency of one country needs to be converted in a second country, in order to ensure that a certain amount of the currency of the first country can purchase the 
same volume of goods and services in the second country; Inflation: measured by the annual growth rate of the implicit GDP deflator, showing the rate of variation of current prices in the economy as a whole; Exchange rate: determined by domestic authorities or in the legally sanctioned exchange market, it is calculated as an annual average based on monthly averages (units of local currency against the US dollar) (IMF, 2017).

The economic indicators cited above were projected at intervals based on the theory of economic cycles, as defined by Keynes (1983), therefore, take into account the upwards and downwards movements which, with a recognized degree of regularity, are active forces in the economic system.

The average duration of these cycles was defined in 1926 by Russian economist Nikolai Kondratiev, based on chronological observations. The so-called long cycle lasts 20 years, i.e., growth, deceleration, contraction, and economic prosperity (cyclical wave), the long cycle is sub-divided into cycles of less than five years (Schumpeter, 1964). Therefore, the economic indicators will be projected five years before the implementation of the PMO.

The time and cost of implementing a PMO depends on a number of factors, such as the company's culture regarding project management processes, amount of people, projects involved, and especially, the support of senior management. In a mature company, it can take approximately six months to implement a PMO, and up to 24 months in a company without a culture of processes, thus, the other parameter for projecting indicators take at least two years from the go-live date of the implementation project. Therefore, the analytical logic of data projection, based on economic theory and project management will be: five years before implementation, two years after the go-live date, at least five years after implementation. In cases of PMOs still in the process of implementation, the economic projection available in the IMF database was taken into account.

\section{Results and Discussion}

The purpose of the distributed questionnaire was to collect data in four blocks of analysis: structure, profile, implementation, and post-implementation results, so as to better understand the workings of the responding CBs. Eleven questionnaires were sent and four were answered, or $36.4 \%$ of the sample population surveyed. The average time of completion for the questionnaire was $49 \mathrm{~m} 54 \mathrm{~s}$, and the respondents had a directive or managerial profile.

Next, the data obtained according to its respective tabulation, research, and interpretation will be submitted, allowing for the general understanding of the PMOs in Central Banks and how, or if, it was adjusted in order to support the economic stability of their countries. To this end, the data will be presented separately, initially focusing on the best practices of project management in conjunction, and later, individually focusing on the postimplementation benefits of the PMOs.

\section{Structure}

Among the respondents, all possessed a project structure $(100 \%$ of the samples), and therefore a PMO. With regard to the geographic location of the respondents, there is a significant distinction between the countries, two European, one from Central America, and one from South America. This diversity enabled an analysis of the PMOs at different angles of performance, in developed as well as in developing nations. Another important indexer used to subcategorize the surveyed counties was the Human Development Index [HDI], an important indicator that evaluates the quality of life and economic development of a population. Annually, the United Nations Development Program [UNDP] releases a report on the key pillars of development, such as health, education, and income, on a scale of 0 (no human development) to 1 (high level of human development) (United Nations Development Program, 2016), according to Figure 1.

It is worth noting that this type of evaluation for understanding the external factors and challenges arising from economies with a high or very high HDI are very distinct from each other and, consequently, affect the $\mathrm{CBs}$, and therefore the project portfolios managed by their PMOs. An indirect proportion determines that the higher the HDI, the lower the need for a strategic PMO, in order to directly impact the economy, which will be better addressed later.

The extent of excellence in project management is basically due to the repetition of processes used in each and every project. This repetition refers to project management methodologies and is understood in the literature that each company must adapt and maintain the most relevant methodologies for their activities. Often, their processes are integrated, and to this end there is an adjustment of one of more methods for managing such project management process (Kerzner, 2013), as regards the methodology of the surveyed population, according to Figure 2.

A preliminary survey was conducted and options for methodologies that could be more adherent to the realities of the PMOs were included in the questionnaire, as follows: $75 \%$ use the methodology of their own central bank (which is nothing more than the set of one or more methodologies, configured to originate its own methodology), such as, for example, the PMOCBB with its own methodology known as MGPRO 3.0; $75 \%$ composed their "own methodology" based on 
the recommendations of the PMI PMBOK guidebook which, despite not being considered a methodology, is a set of recommendations and standards; $25 \%$ use Capability Maturity Model Integration [CMMI], a model with a set of good practices in specific disciplines such as software, products, suppliers, etc.; 25\% use Projects in Controlled Environments [Prince 2], a methodology that presents a complete and integrated framework of a project, not only in the project's spheres of knowledge, but also in specialized contributions, such as how developing a product implies design, manufacturing, and technical areas.

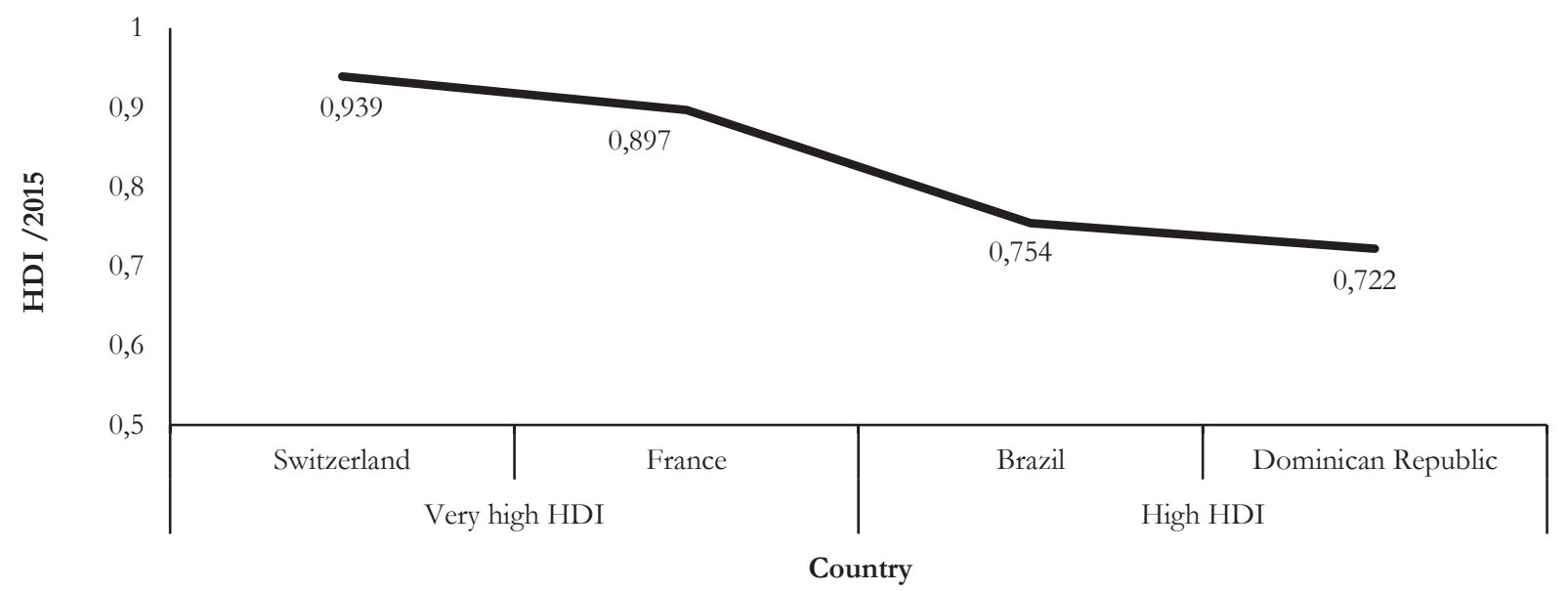

Figure 1. Countries according to the Human Development Index [HDI] Source: based on the UNPD (2016)

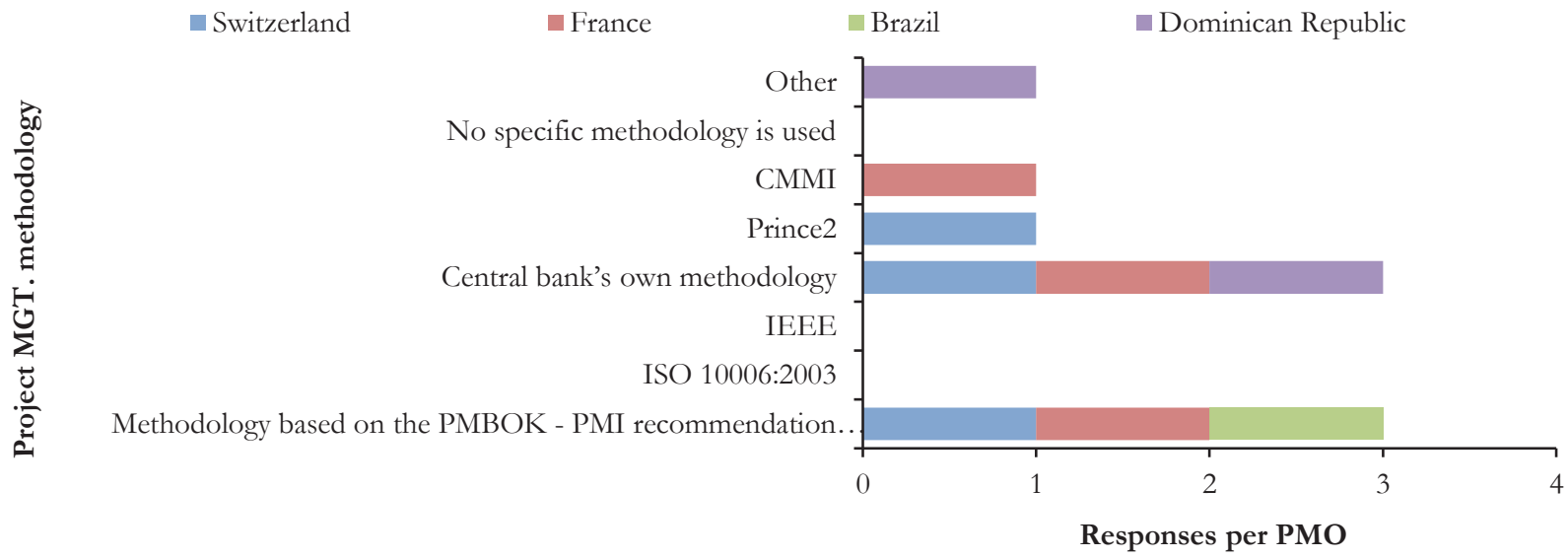

Figure 2. Project management methodology per Project Management Office [PMO]

*MGT: Management; CMMI: Capability Maturity Model Integration; IEEE: Institute of Eletric and Eletronic Engineer; ISO: International Organization for Standardization; PMBOK: Project Management Body of Knowledge

In the "other" field, the PMO-CBDR signaled that the PMO's own methodology was developed according to the standards of PMI: PMBOK, Portfolio, Program, OPM, and Organizational Project Management Maturity Model [OPM3], guide for improving processes and increasing the maturity measurement of projects, under analysis of a broad set of organizational best practices.

A PMO's length of existence can generally indicate which phase it is in: implementation, maturity, or consolidation, analyzed below in Figure 3.
In the maturation phase, $75 \%$ of the sample population with more than ten years, it is worth noting that the PMO-CBB began its maturity program in 2011, achieving a maturity level of 4.2 in 2014, according to the de PRADO-PMMM technical criterion (Caracas e Cota, 2014), and the PMO of the PMO-CBDR uses PMO 3 as a methodology for maturity. In the implementation phase, of which $25 \%$ are between one to two years, we have the case of the PMO of the Swiss National Bank [PMO-SNB] building a project management structure based on the 
best practices and methodologies presented herein. One must take into account that the average implementation of a PMO, depending on the organization structure and resources, can take from six to 24 months.

As for the size PMOs in each CB, the survey included entries on the amount of employees, starting with less than five people and up to more than 50, including managers and directors, according to Figure 4.

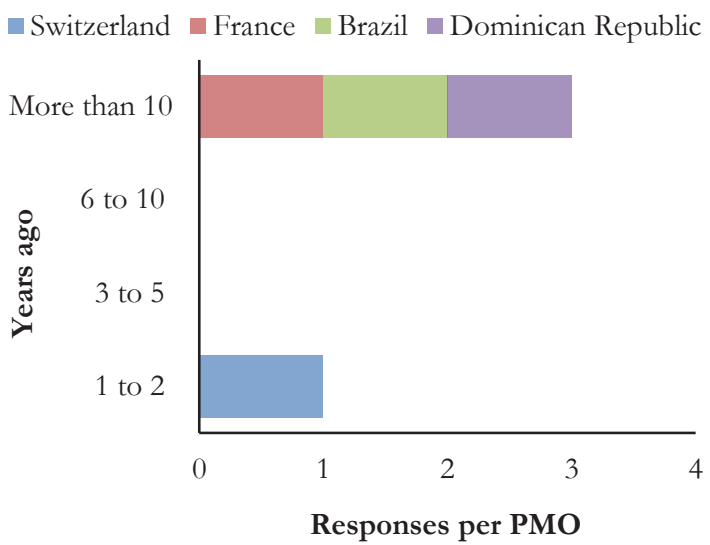

Figure 3. Project Management Office [PMO] implementation timeframe

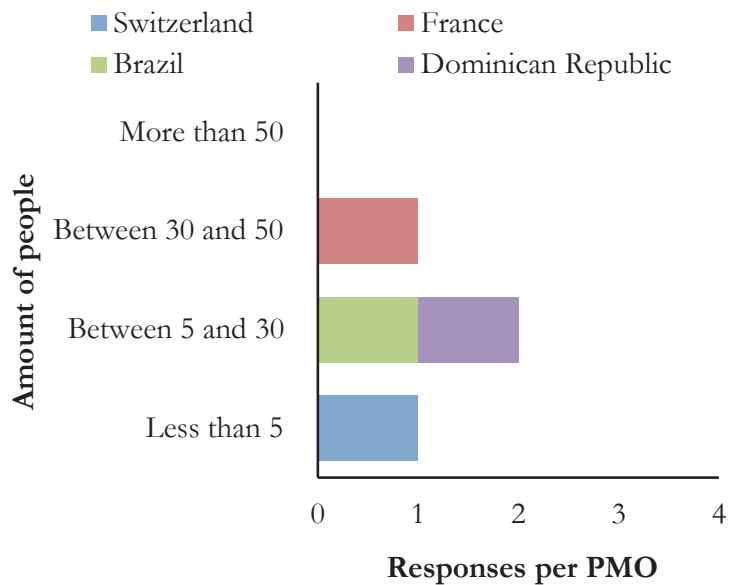

Figure 4. Amount of people per Project Management Office [PMO]

Although there is no specific recommendation in the literature as to the size of a PMO, especially in a CB, i.e., a standard of minimum and maximum number of members, it is known that the determining factor for defining this item is the size of the organization; the smaller it is, the fewer projects can be carried out simultaneously while, on the other hand, large organizations involve several highly complex projects at the same time, thus requiring a larger cross-functional team (Barcaui, 2012). It was identified that $50 \%$ of those interviewed have a project team of between five and 30 people; $25 \%$ have between 30 to 50 people, the case of the PMO of "Banque de France" - the Central Bank of France [PMO-BF] with the largest PMO structure among the surveyed population; $25 \%$ have less than five people, such as the PMO-SNB which is in the implementation phase, and is still formatting its operational project structure.

\section{Profile}

As initially mentioned in the paper, each PMO has its own characteristics; its way of operating, profile, and roles are intrinsically linked to the organizational strategy of a company. The classification of the types of projects managed within a PMO allows for the recording of information, such as duration, costs, complexity, and risks, among others, enabling the management of other equivalent projects to be managed with a historical basis and, consequently, more effectively and with little margin of error, as lessons learned are always a good reference. The questionnaire was developed taking into account the types of projects that could be more adherent to the activities of the CBs, according to Figure 5, below.

It was noticed that $75 \%$ of the respondents developed software development projects. We can cite, as an example in this type, the projects developed by some central banks and regulatory bodies around the world during the period of the 2008 financial crisis, which was aggravated by the lack of regulation in the subprime stock market. As a consequence, regulatory parameters and algorithms with more precise classification criteria were established in credit granting systems. Here it is observed how this type of project can have an impact on the economy, once developed in order to control the world economic crisis in place during the period in question. The data from 75\% of the projects comprises studies, analyses, and design, and $50 \%$ are initiatives of economic conjecture. Although only two respondents carry out this type of project, they confirm something that is possible to identify in case studies published on other CBs: there are other types of projects that indirectly affect aspects of economic conjecture such as, for example, the first type mentioned in this item of the questionnaire. Other data assessed: $25 \%$ engineering and infrastructure; $25 \%$ services and products, and $25 \%$ other, specified by the PMO-CBDR that does not develop administrative initiatives, is the type of control of the PMO.

The specific role of the PMO is played out at three level, from providing assistance to direct responsibility for project management, classified in the questionnaire as "PMO's level of operation and expertise", elucidated by Maximiniano (2014), in the levels of Support, Control, and Directive. To understand at which level each PMO operates on allows us to analyze the degree of influence of the projects on the PMI organization PMI (2013), and how directly they impact the corporate strategy, as presented in Figure 6, below. 


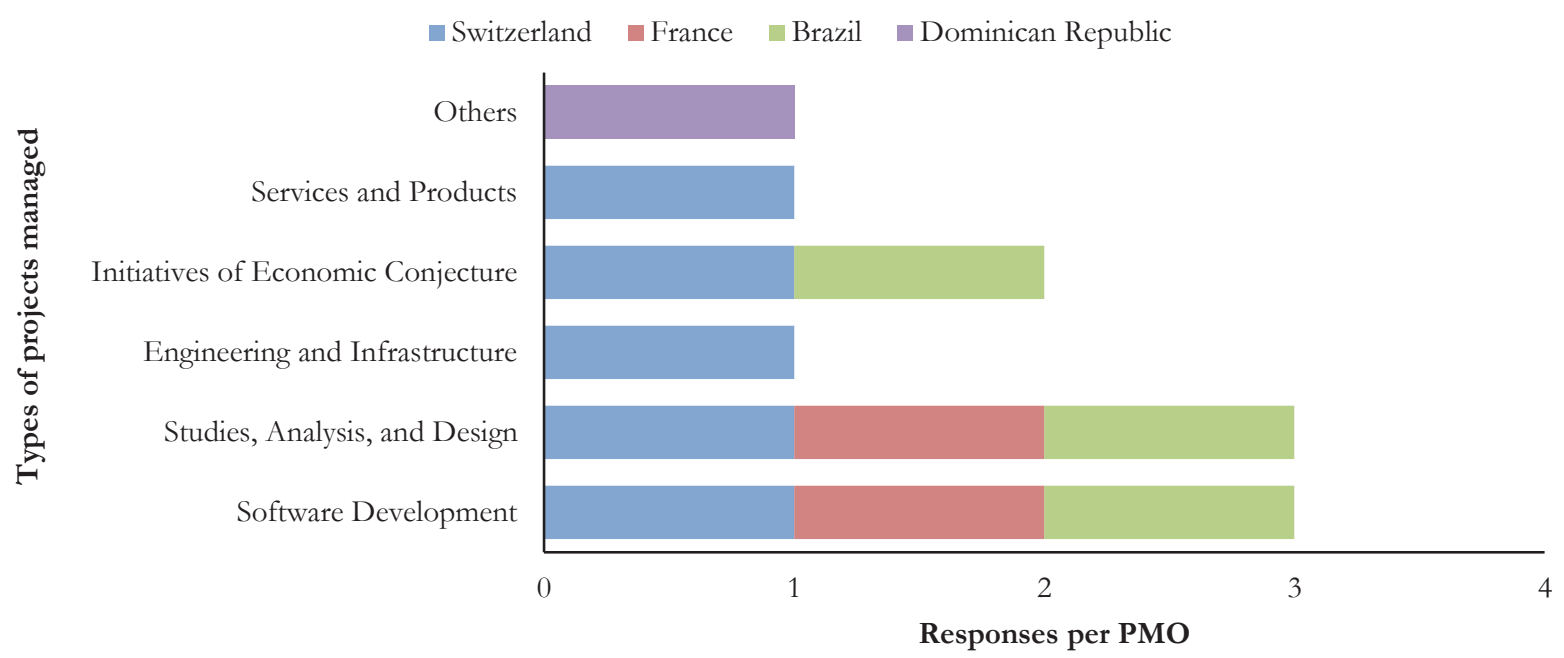

Figure 5. Types of projects managed by Project Management Office [PMOs]

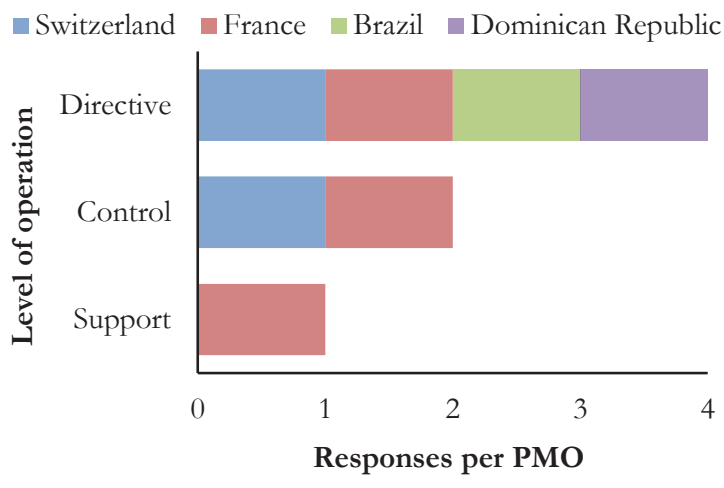

Figure 6. Level of operation of the Project Management Office [PMO]

Level 1: project support office, operates in project consulting, providing templates, issuing reports with a low level of control in functional areas, and represents $25 \%$ of the respondents; Level 2: project control office, in addition to the project support routines, it also promotes management control and assistance, this PMO has an average level of control in functional areas, representing $50 \%$ of the respondents; Level 3: strategic project office, in addition to control and support activities, it operates on an directive and strategic management level, corresponding to $100 \%$ of the respondents. Returning to the concept of HDI, we noted that PMOs with a very high HDI have two levels of operation: strategic and support, while high HDIs operate at a strategic level. This can be justified by a country's degree of vulnerability to external shocks, because the higher the HDI, the lower the need for emergency crisis or economic recovery projects. However, there is a bias in this item, since some CBs have more than one PMO and with different profiles, divided into business units; PMOs focused on quick projects such as developing information technology or providing support to functional areas, while another PMO focuses on organizational strategies and business development, and may or may not interface with the areas that carry out strategic follow-up. For example, the Central Bank of Brazil has four PMOs: a corporate office, which serves the entire organization, and three sectors: the supervisory board, the department of information technology, and the corporate university.

Although a PMO can operate on one or more levels, as confirmed in the survey, according to Kerzner (2013), this type of managerial level, usually applied to traditional structures, is undergoing redefinition. The operational basis of each level remains the same, however, the application is different, since the role of temporary project manager, or even, outsourced project offices, is increasingly being contracted, thus, assuming varying levels of operation, as required by the organization. Therefore, although Maximiano classifies PMOs with levels of operation, Kerzner emphasizes that this classification can be changeable.

The closer the PMO is to the directive level, the more direct is its relationship with the strategic initiatives of its corporation. Nevertheless, the Office of Strategic Management [OSM] appears in the corporate scenario, a new department created to carry out strategic management activities in large and complex organizations, but it is worth mentioning that in some companies, the PMO takes on this role (Kallas and Coutinho, 2005). The PMO is directive and handles strategies in CBs, where the projects managed in portfolios contribute to their strategic mission, which in intrinsically related to the maintenance of price stability, the efficiency of the regulation of the financial system, and monetary policies in order to contribute to economic stability. In other words, the more strategic it is, the more direct will be its impact on the economic stability of the country, regardless of the HDI. However, there 
are other variables that affect the ratio of PMO activities to economic stability, which will be defined later in the post-implementation benefits section, where the actual macroeconomic impacts will be presented. Data isolated from the survey does not make it possible to identify such correlation.

\section{Implementation}

To understand the process of implementing a PMO, searching for the reason it was conceived, the difficulties in the initial stages to the people actually involved in the process, allows us to understand if there are similarities in the structuring format of these and/or if there is a systematic pattern for such structures, foremost what were the determining factors for obtaining such expressive results in the surveyed PMOs.

Regarding the reasons for the implementation of each PMO, it was envisioned to contextualize the intent, to the detriment of some external factor, especially if the $\mathrm{CB}$ of the country in question needed to act effectively in the resolution of some economic crisis, or perhaps to manage more effectively, according to Figure 7.

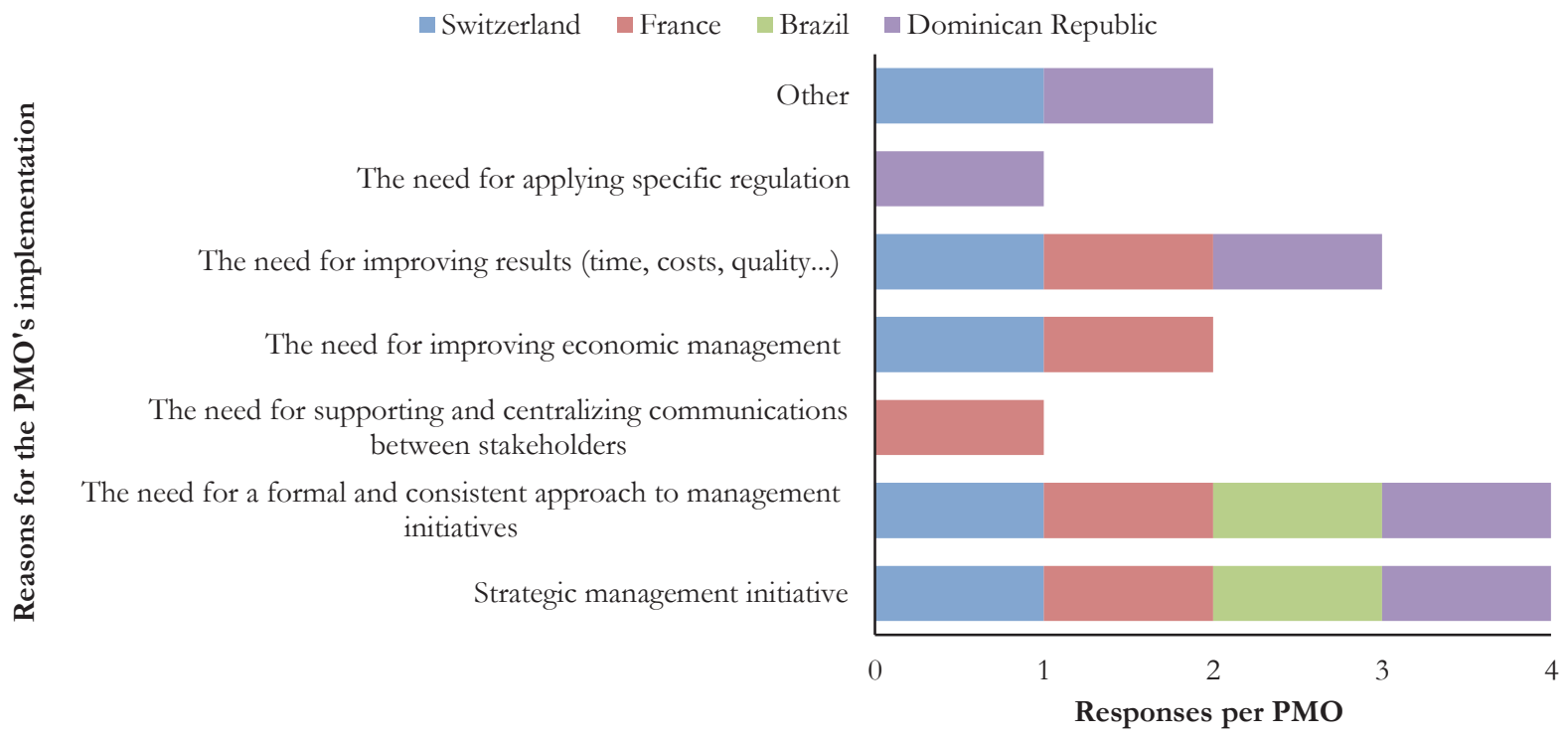

Figure 7. Reasons for the implementation of the Project Management Office [PMO]

All of the PMOs, i.e., 100\% of the sample, emerged due to three main aspects: strategic management initiative, the need for a formal and consistent approach to management initiatives, and the need for improved results, such as time, cost, quality, etc. $50 \%$ were due to the need for improved economic management and the need for supporting and centralizing communications among the stakeholders involving the CB.

There is a coinciding factor for determining the origin of high HDI CBs: both faced a severe economic crisis while the PMO-CBDR was born of the need for a department that would work to meet the strategic targets that were becoming more challenging due to the economic crisis the country was facing; the PMO-CBB, on the other hand, emerged in the midst of a severe crisis in the Brazilian banking system, creating the first project centers in partnership with the World Bank to implement specific regulation. Thus, $50 \%$ of the sample emerged from an unstable economic scenario.

In the "other" field, answered by $50 \%$ of the sample, the PMO-CBDR had to contribute to the country's macroeconomic recovery, foreign exchange, and financial stability through a strategic management of the organization, and the PMO-SNB had to ensure that projects were managed in accordance with the best management practices.

There are many challenges involved in the implementation of a PMO, and whether in the private or public sphere, the difficulties are part of the course. However, it is emphasizes that independent federal agencies have more challenging implications, according to Kerzner (2013). There are several reasons for this, among them, there is little tolerance for failure, because the impacts directly reflect on economic performance and, in general, on the day to day lives of millions of people; they involve several layers of stakeholders with often conflicting interests; they operate in a greatly vulnerable and oscillating environment; among others. The questionnaire was compiled taking into account the internal difficulties, therefore, internal challenging factors in the initial stages of implementation of the PMO, visible below in Figure 8. 


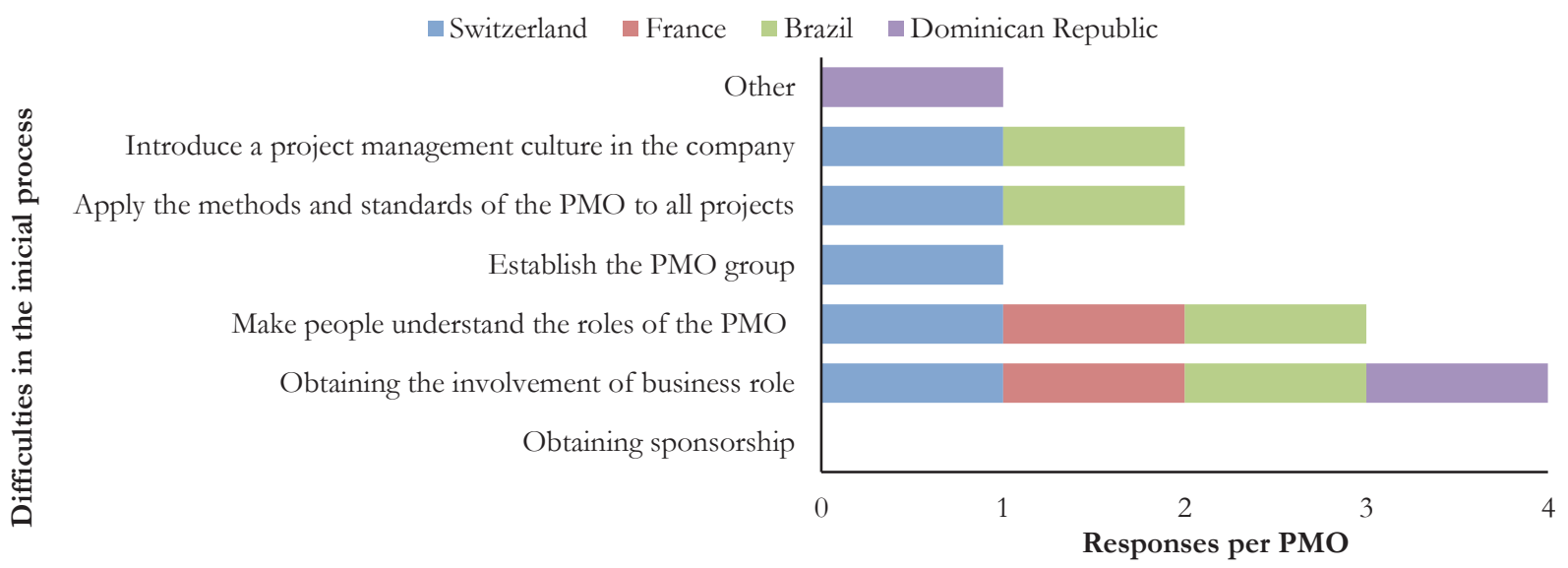

Figure 8. Difficulties in the initial processes of implementing the Project Management Office [PMO]

The totality of the sample population, i.e., $100 \%$ of those interviewed, found it difficult to obtain the involvement of business roles, as seen in the "profile" item of the questionnaire. Some PMOs play a role in supporting functional areas in the development of projects, since most institutions have difficulties in this regard, and functional managers often justify not using PMO standards to manage their projects, claiming that they were delivering results without project methodologies, and therefore not engaging with the project manager (Barcaui, 2012); 75\% with the item to make people understand the roles and possible progression with the implementation of a PMO; $25 \%$ to establish the PMO group; 50\% to introduce a project management culture in the company; It was noted that among the most relevant items are intrinsically related to the item "human resources management", a sphere of knowledge strongly approached in project management training curricula. $50 \%$ difficulties in applying to all projects the methods and standards of the PMO. Another relevant aspect is that within the sample, $0 \%$, i.e., no $\mathrm{CB}$ had difficulties in obtaining sponsors in the initial stages of implementation, perhaps due to the corporation having understood, still in the process of initialization, how the PMO's mission could benefit the institution as a whole.

In the "other" field, the PMO-CBDR encountered difficulties in ensuring that the team responsible for conducting the projects remained focused only on their own duties. This is a challenge in any sphere, as projects centers are allocated within functional areas, where the boundaries between functional activities and projects often intersect.

The market is seeing an increase in consultancies whose business in the implementation of PMOs in contracting companies, and the purpose of this item of the survey is to identify by whom the implementation activities were conducted, whether by these external consultants, internal staff, or a hybrid team, according to Figure 9.

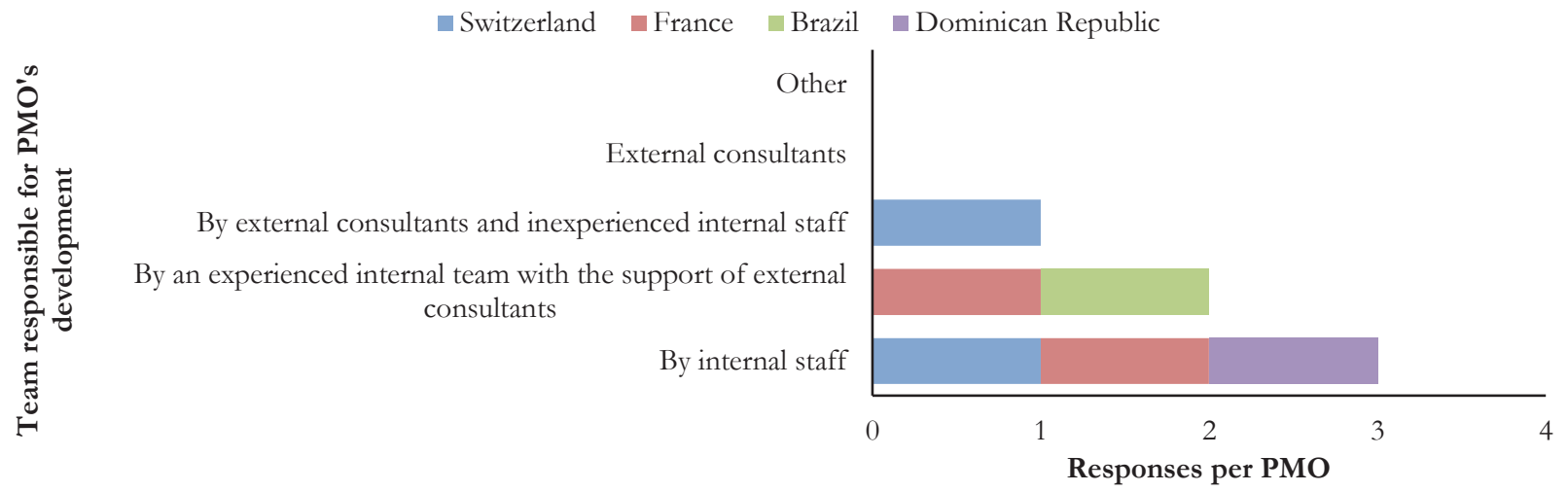

Figure 9. Team responsible for the creation and development of the Project Management Office [PMO]

The implementation of the PMO from internal staff corresponded to $75 \%$ of the sample population, which shows an internal predisposition in the company culture for project-oriented activities. 50\% assembled an implementation team comprising an experienced internal team with the support of external consultants, while $25 \%$ used external consultants and inexperienced internal staff. Note that $0 \%$ of the sample exclusively 
used external consultants for the implementation of the PMO, which is plausible for this type of institution. Generally, working in partnerships or obtaining data from independent federal agencies entails rigorous analysis, and institutions usually opt for greater internalization of possible processes in order to ensure greater control and confidentiality of information.
There is no question that the surveyed population has a center of excellence in project practices, however, the level of quality currently achieved is a reflection of the successful implementation of each PMO. The next item of the survey aimed to understand the respective determining factors of success in the implementation process, according to Figure 10.

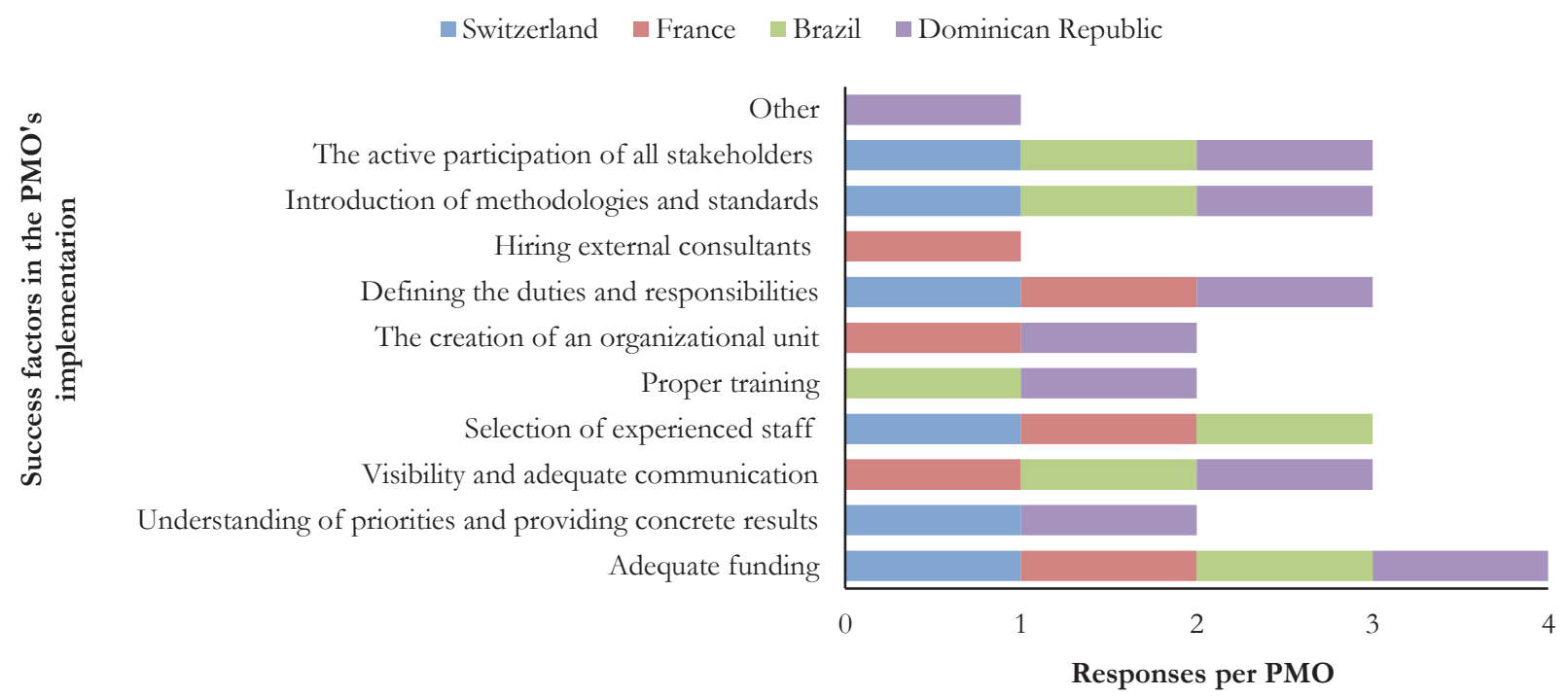

Figure 10. Success factors in the implementation of the Project Management Office [PMO]

The entire sample population, therefore $100 \%$, attributes the successful implementation of the PMO to adequate sponsorship in the initial processes, highlighting the sponsor of the PMO-CBB, whereas the World Bank contributed capital (Carneiro, 2010); 75\% attributed to the factors: visibility and adequate communication of the PMO's initiatives throughout the company; definition of duties, roles, and responsibilities of the PMO; introduction of methodologies, standards, and tools; selection of experienced staff with specific skills; The active participation of all stakeholders (Project / Program Manager, upper management, middle management,...). $50 \%$ of the sample associated successful implementation with the following factors: proper training; the creation of an organizational unit; the understanding of priorities and providing concrete and immediate results. While 25\% attributed success to hiring external consultants.

In the "other" field, the PMO-CBDR also attributes success to other factors, stating that success is based on strategic alignment and the collaborative management of all project managers, not on "bloodthirsty" promoters and incident supervisors, but negotiators to help in the resolution of conflicts.

\section{Post-implementation results}

The benefits generated after the implementation of a PMO in the organization allow for reflection and for having a clearer view of positive impacts on the CBs and, foremost, how project management has effectively contributed to the economic stability and maintenance of each country, thus achieving the mission for which the CBs themselves were conceived. When benefits are mentioned, the last part of the questionnaire reserved a specific field for PMOs to describe and share cases of success and actual results achieved after the implementation procedure. Below is a detailed description of the benefits generated post-implementation, as well as cases of success.

The PMO-SNB highlighted that the main postimplementation benefit, in these early stages, was transparency in the project portfolio; effective discussion in the requisition of resources; increased quality of projects and more flexibility in resource allocation. Regarding cases of success, it was mentioned that the PMO is currently focused on establishing a methodology and standards within the organization, and therefore, members of the $\mathrm{PMO}$ are not yet actively managing projects.

The PMO-BF highlighted that they obtained results from $70 \%$ of the projects, committed in terms of cost, time, and perimeters. As a case of success, they shared the 3rd Capability Maturity Model Integration [CMMI] evaluation, which has occurred since 2011, a tool aimed at improving and controlling organizational processes, as well as the continuous evaluation of every project and elevated maintenance, controlled monthly through their own tools. 
The PMO-CBB obtained as a benefit the standardization, consistency, benchmarking, and systematization between the all of the projects. It is also worth mentioning the creation of corporate project and portfolio management rites, with the standardization of practices and language, improved definition of scope and targets, and integration between departments. One case of success was a project with a long development cycle that lasted 7 years in 3 phases, whose objective was to increase the maturity of the CB in project, program, and portfolio management. It is also worth mentioning a large training center that was established, with over 1000 training sessions since 2008. In 2013, one major project was the partnership with the British embassy for the implementation of portfolio management. Approximately 80 projects are executed per year, with a portfolio of approximately US\$ 50 million annually, as well as sufficient human resources for such executions (Aguiar et al., 2014).

Lastly, the PMO-CBDR highlighted as benefits achieved: first, the strategic alignment focusing on the efforts of the organization to achieve strategic objectives and targets; the deliveries that went into operation allowed for the improvement of macroeconomic models for the decision making of monetary policies; the adoption of an inflation targeting scheme; mechanisms for the transmission of monetary policy and changing from the base year to the system of accounts and the Consumer Price Index [CPI].

Likewise, laws and regulations for strengthening the financial system, the implementation of an early warning system to control the risk of financial institutions, public auction system, design and implementation of the Dominican Republic payment system [SIPARD], including the start of the RTGS system for the settlement of pf payments and securities in real time, and the design and implementation of the human capital system. Achieve project portfolio performance 20062013 of the organization's goals by $97 \%$ and projects completed on time $(82 \%)$, and budget $(95 \%)$. The Central Bank of the Dominican Republic also acted as a sponsor for the formation of the PMI Chapter in the Country. In this field, cases of success, they shared that the implementation of the PMO-CBDR was a program carried out by the PMO itself, with the goal of ensuring the successful implementation of the Institutional Strategic Plan. The preliminary idea developed the definition of the type and scope of the PMO, designation of the implementation of the management of Programs, bibliographic research and Benchmarking to formulate the definitive implementation program, started on January 1, 2007. This program included PMO staff training programs, the approval of the structure, cultural change, technological tool and methodology. The projects carried out under the PMO's control helped contribute the country's macroeconomic, exchange, and financial recovery, and to fulfill the social responsibility of promoting in all sectors the good practices of project management in the pursuit of the best allocation of resources for such purposes. Both activities, the realization of benefits and social responsibility, were the main success factors for the CBIM-PMO award, 2014 PMI PMO of the year finalist, the first Latin American PMO to reach this position.

It is important to point out that the corporate economic scenario and, in general, the duties of the PMO are constantly changing, which is why the questionnaire includes an item that allows us to understand the challenges of each PMO, below in Figure 11.

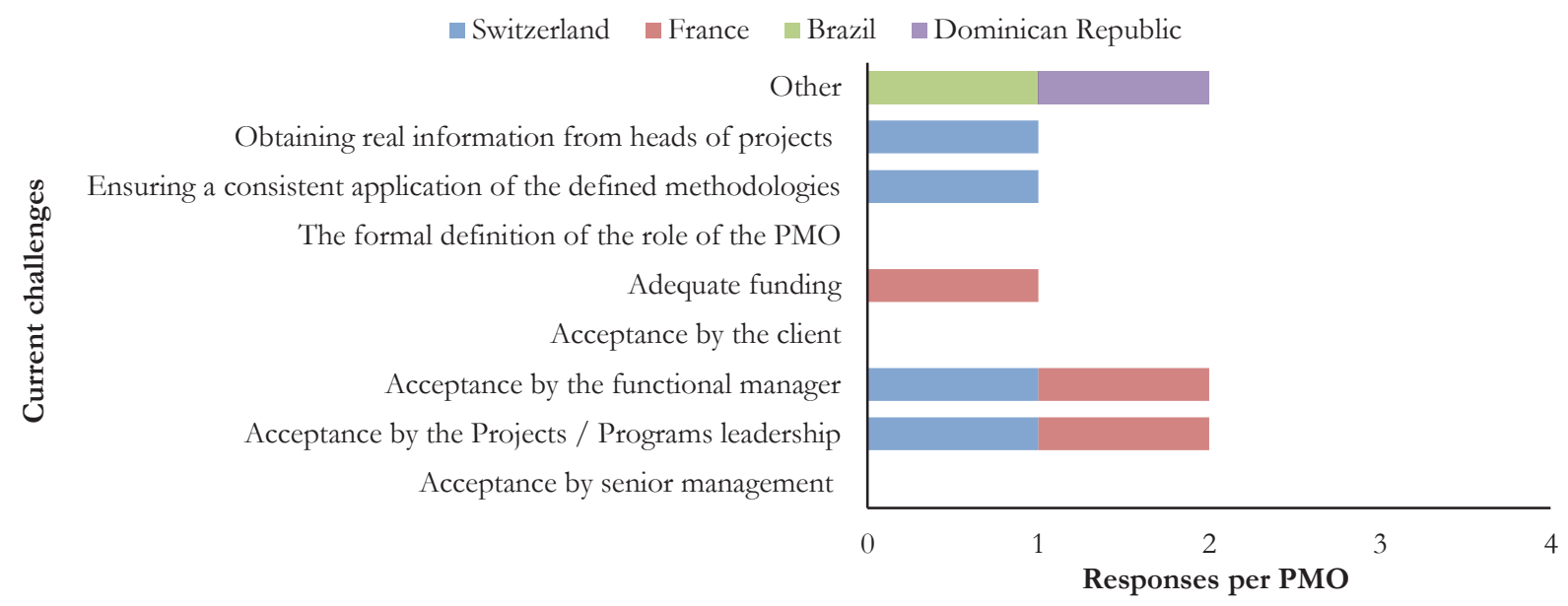

Figure 11. Current challenges post Project Management Office [PMO] implementation 
Half of the sample population, i.e. $50 \%$, share the respective challenges and difficulties: Acceptance by the functional manager; Acceptance by the Projects / Programs leadership; $25 \%$ of the sample with adequate funding; ensuring a consistent application of the defined methodologies; obtaining real information from heads of projects / programs.

In the "other" field the PMO-CBB shared that the current challenge is to work on the next steps: portfolio and program management. The PMO-CBDR also expressed that its current challenge is to continue the maturation process until they become a center of excellence, which is the initiative projected for 2018.

\section{Macroeconomic impacts}

Until this part of the study, the significant positive impacts in the various spheres that cover a PMO have been observed. Next, an analysis was made to determine if there actually was macroeconomic stabilization, growth, or deceleration in the respective countries, to the detriment of the implementation period. The period evaluated, as mentioned in the methodology field, made use of four instants, such as: central factor,
PMO implementation timeframe $(\mathrm{t})$, minus five years from $(\mathrm{t})$, minimum of five years after $(\mathrm{t})$, and, finally, an economic performance projection developed by a team of IMF experts for 2017 to 2022. Constant values were taken into account in the interpretation of results, i.e., not addressing factors such as international crises and local crises of a political, financial, fiscal, or any other nature. We begin with countries with a high HDI, which are generally more susceptible to fluctuations because of the high degree of dependence on neighboring economies, and a large part of the GDP is usually tied to commodities (Keynes, 1973).

In the case of the PMO-CBDR, according to the directive body of the $\mathrm{PMO}$, in an interview given when it was a candidate to the PMI PMO of the year award on an international level, from its initial stages, projects were executed for macroeconomic reach and financial stability, as well as institutional strengthening, which consisted of a portfolio of 345 projects, of which $97 \%$ were completed, meeting the strategic targets of the corporation (PMI, 2014). These positive impacts in an economic context can be seen in Figure 12.

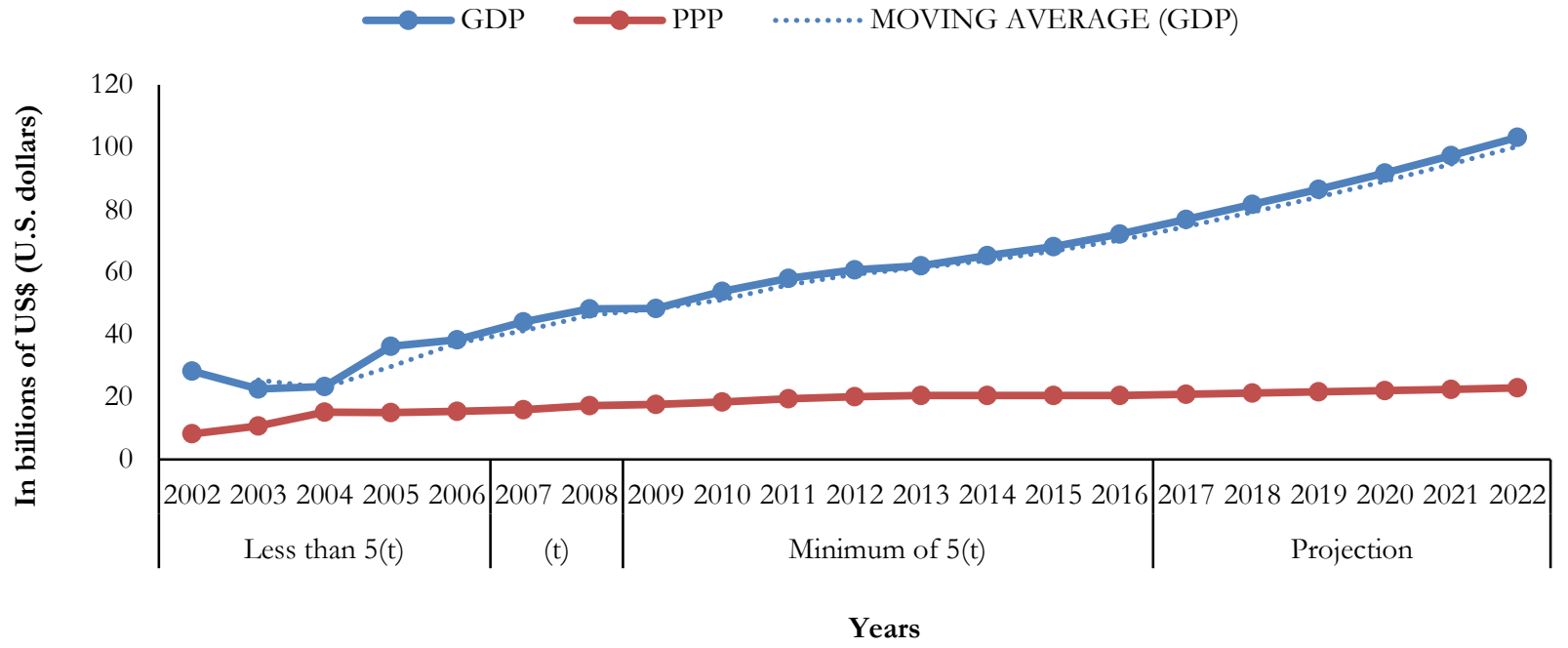

Figure 12. Macroeconomic impacts in relation to (t), Project Management Office - Central Bank of Republic Dominican [PMO CBDR]

Source: based on IMF Data, IMF (2017)

There was a significant improvement in economic performance and, in addition, it was identified that inflation dropped from $49 \%$ to $7.25 \%$, the exchange rate from RD $\$ 65$ pesos to RD\$35 pesos / US\$ 1 dollar, and the interest rate also declined from 35\% to $13.09 \%$, (PMI, 2014). Between 2002 and 2016, there was an increase of 155.08 percent increase in GDP performance.

Regarding macroeconomic performance after the implementation of the PMO-CBB, it should be noted that it was conceived in the midst of a banking crisis, and together with the World Bank, to establish metrics and standards that would contribute to improving project performance and, consequently, economic performance, which was in the midst of a major collapse. During the collaborative participation in projects, it had access to the best practices performed by the World Bank Banco Mundial, resulting in easily noted positive impacts, according to Figure 13. 


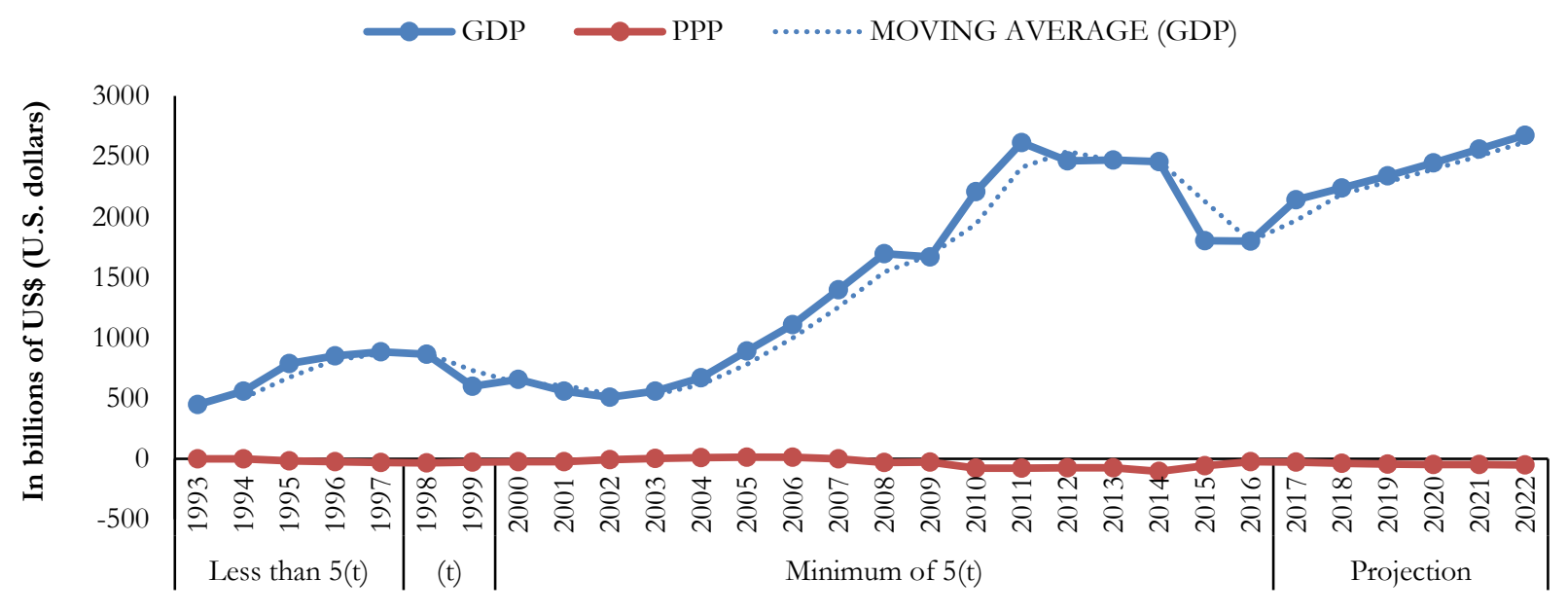

Years

Figure 13. Macroeconomic impacts in relation to $(\mathrm{t})$, Project Management Office - Banco Central do Brasil [PMO - BCBR] Source: based on IMF Data, IMF (2017)

Note that there is a gradual improvement in economic performance, and inflation in the year of the implementation of the PMO (1998) was 3,196, being reduced to the current 8.74. Between 1993 and 2016, there was a 99.59 percent increase in GDP performance.
In the case of countries with a very high HDI, with less volatile currencies and less elasticity to external shocks, the indicators remain constant. Below is the economic performance in relation to the PMO implementation period $(\mathrm{t})$ of the PMO-BF, according to Figure 14.

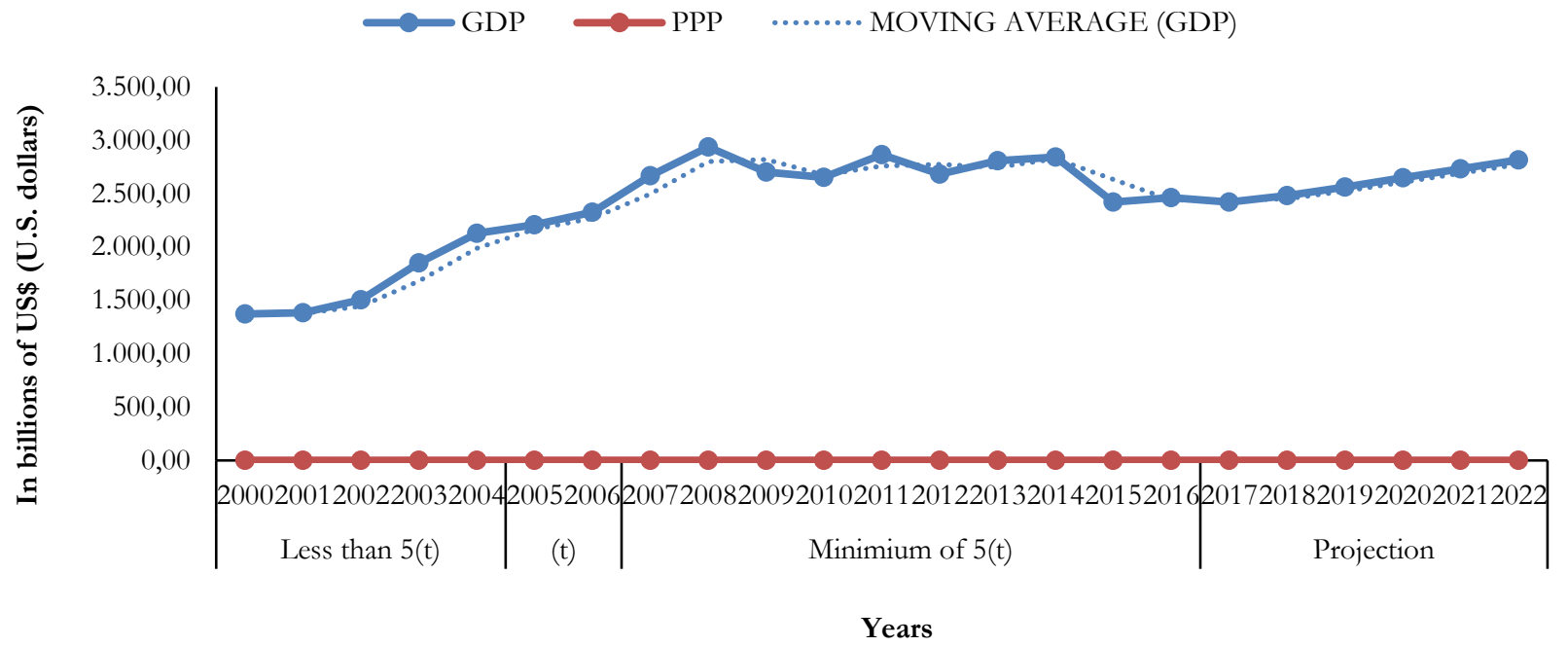

Figure 14. Macroeconomic impacts in relation to ( $\mathrm{t}$ ), Project Management Office [PMO - BF] Source: based on IMF Data, IMF (2017)

Note that economic performance is practically constant, but between 2000 and 2016, however, in terms of GDP, there was an increase with a percentage variation of 79.47 .

Switzerland is located in Europe but is not part of the European Union; it a country with great liquidity in its economy. Below are the respective economic impacts, though it is worth mentioning that the respective PMOSNB is in the implementation phase, and, therefore, it is not possible to accurately view the real impacts. For this reason the "minimum of $5(\mathrm{t})$ " field was disregarded, since the 5 years after implementation are in the "projection" field, corresponding to the years of 2018 to 2022, represented in Figure 15 below. 


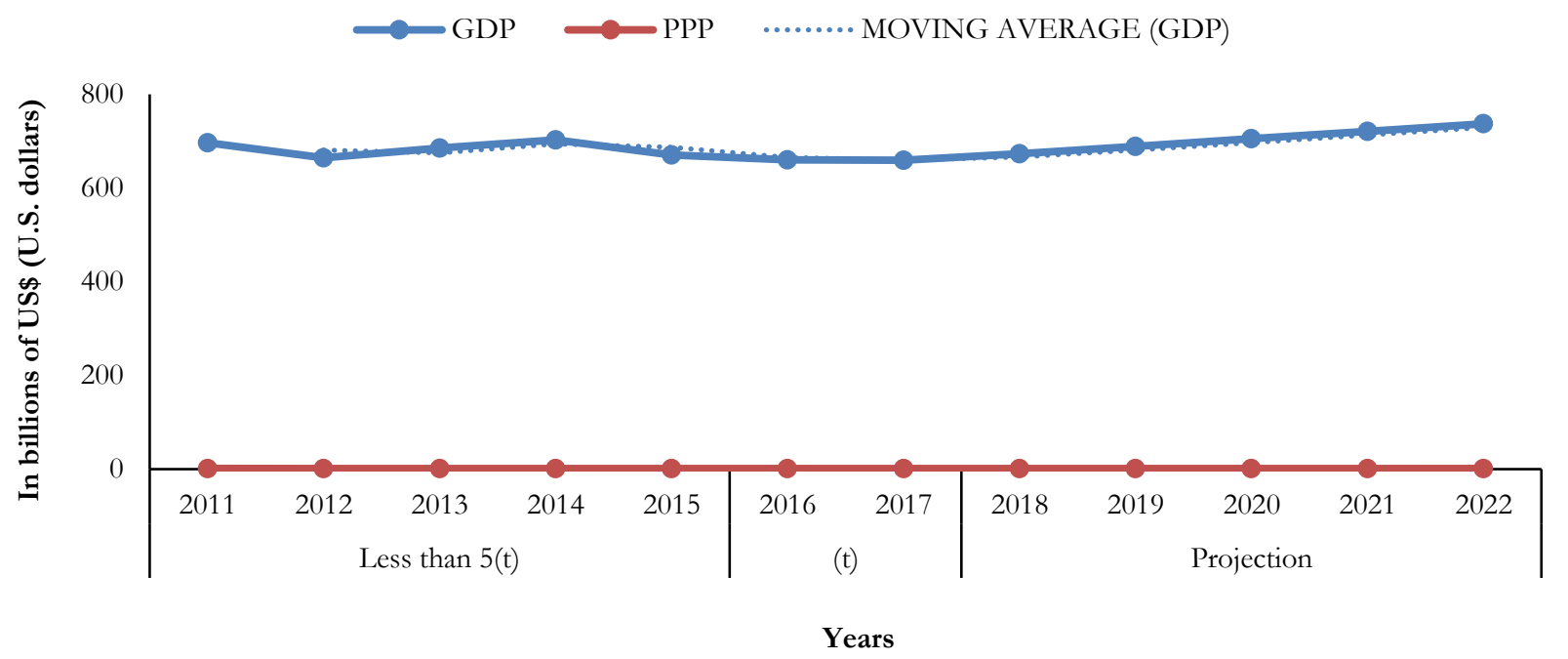

Figure 15. Macroeconomic impacts in relation to (t), Project Management Office - Services \& New Business [PMO - SNB] Source: based on IMF Data, IMF (2017)

Note that even taking into account the projection, economic performance will be practically constant, with a projected percentage variation of 5.825, between 2011 and 2022, in terms of GDP.

\section{Conclusion}

Considering the content of the survey and through the applied methods, the study shows that although the PMOs in CBs are created for the direct purpose of impacting the economy, as an expected result, it has been proven that they have an indirect impact on economic indicators. It is assumed that the PMOs are agents that promote institutional changes in order to achieve their strategic goals. If the Central Bank's mission is to be generally active in the maintenance of economic health, there is an indirect impact between project management and economic stabilization, whether in terms of stabilization, recovery, or economic growth.

Based on the questionnaire given, it was determined that PMOs operating at a directive level, especially in countries with a high HDI alto, can develop projects that reflect more on economic recovery and maintenance indicators, while PMOs in countries with a very high HDI do not have enough reach to practice projects with significant economic improvement.

It was also weighed that, in economic scenarios, there are a large number of variables that can impact its performance, whatever may be the country's HDI, whether it is developed or developing, or facing the effects of an economic crisis; one thing is for certain: there will always be the effect of economic cycles, and therefore, there is no such thing as a magic formula. Using projects as a tool for economic improvement such as in meeting a small company's targets, is an art to be practiced and, as the Germans say: "Übung macht den Meister", or practice makes perfect. This is what every PMO of the surveyed CBs have pursued: excellence in the practice of projects to help their countries and institutions achieve their strategic goals.

As a future challenge, we propose expanding this survey to include a larger number of central banks, with more variables to be weighed, and covering the long economic cycle of 20 years, thus covering all phases of economic performance under the effect of the small 5 -year cycles. Perhaps with this, we could provide, on an academic and business level, the formula to success that the practice of projects has to offer us in business, administrative, operational, and why not, economic terms.

\section{References}

Aguiar, B.P.; Prado, D.; Carvalho, M.; Cota, M.; Caracas, S.; Archibald, R. 2015. Maturity Growing: Brazil Central Bank Case. In: PM World Journal v. IV, Issue IX - September 2015.

Barcaui, A. (org.). 2012. PMO: escritório de projetos, programas e portfólio na prática. Brasport, Tijuca, RJ, Brasil.

Bolles, D. 2002. Building Project Management Center of Excellence. AMACOM Books, New York, NY, USA.

Caracas, S.; Cota, S. 2014. Project Management Maturity: The Central Bank Case Study. Disponível em: <https://www. falconi.com/wp-content/uploads/2014/11/Artigo-caseBanco-Central-PMWJ.pdf.> Acesso em: 02 abr. 2017.

Carneiro, M.F.S., Valle, J.A.S do, Cota, M.F.M., Soares, C.A.P. 2010. Gestão Pública: O papel do planejamento estratégico, gerenciamento de portfólio, programas e projetos e dos Escritórios de Projetos na Modernização da Gestão Pública. Brasport, Rio de Janeiro, RJ, Brasil.

Chiu, Y.C. 2010. An Introduction to the history of Project Management: From earliest times to A.D. 1900. Eburon, 
Delft, Netherlands.

Crawford, L.; Helm, J. 2009. Government and governance: the value of project management in the public sector. Project Management Journal, 40(1), 73-87.

Diehl, A.; Tatim, D. 2004. Pesquisa em ciências sociais aplicadas: métodos e técnicas. Pearson Prentice Hall, São Paulo, SP, Brasil.

Fundo Monetário Internacional [FMI]. 2017. IMF Data. Disponível em: <https://www.imf.org/external/data.htm>. Acesso em: 19 abr. 2017.

Hallows, J.E. 2002. The Project Management Office tollkit. AMACON, New York, NY, USA.

Kallas, D.; Coutinho, A.R. 2005. Gestão da Estratégia: Experiências e lições de empresas brasileiras. Campos, Rio de Janeiro, RJ. Brasil.

Kerzner, H.R, 2013. Project Management: A system approach to planning, scheduling and controlling. John Wiley \& Sons, New York, NY, USA.

Keynes, J.M. 1973. A Teoria Geral do Emprego, do Juro e da Moeda; Inflação e deflação. Em: Coleção Os Economistas. 1983. Makron Books, São Paulo, SP, Brasil.

Lastra, R.M. 2000. Banco central e regulamentação bancária. Del Rey, Belo Horizonte, MG, Brasil.

Maximiniano, A.C.A. 2014. Administração de Projetos: Como transformar ideias em resultados. Atlas S.A., São Paulo, SP, Brasil.

McCormick, T. 2009. William Petty: And the Ambitions of Political Arithmetic. Oxford. Great Britain, Reino Unido.

PM Tech. 2016. Estatísticas sobre o PMI. Disponível em: $<$ http://blog.pmtech.com.br/dados-estatisticos/>. Acesso em: 11 abr. 2017.

Project Management Institute [PMI] Northern Italy Charpter. 2017. Questionário observatório PMO. Disponível em <http://www.pmi-nic.org/digitallibrary/questionario_ osservatorio_pmo.pdf $>$. Acesso em: 11 abr. 2017.

Project Management Institute [PMT. 2013. Um Guia do conhecimento em gerenciamento de projetos. Guia PMBOK®. 5ed. Project Management Institute, Atlanta, GA, USA.

Project Management Institute [PMT]. 2014. PMO of the year award. Disponível em: <http://www.pmsolutions.com/ articles/PMO-of-the-Year-2014_ebook.pdf $>$. Acesso em: 11.abr.2017.

Project Management Institute [PMI]. 2017. Quem são os gerentes de projetos. Disponível em: <https://brasil.pmi. org/brazil/AboutUS/WhoareProjectManagers.aspx $>$. Acesso em: 09 abr. 2017.

Project Blue Magazin. 2016. Projekt management der Superlative im Gotthard-Basistunnel. Disponível em: <http://www.bluepm.eu/magazine/projektmanagementder-superlative-im-gotthard-basistunnel>. Acesso em: 11 abr. 2017.

Schumpeter, J.A. 1964. A teoria do desenvolvimento econômico. Em: Coleção Os Economistas. 1982. Makron Books, São Paulo, SP, Brasil.

United Nations Development Programme. 2016. Overview Human Development Report 2016. Disponível em: <http://hdr.undp.org/sites/default/files/HDR2016_EN_ Overview_Web.pdf $>$. Acesso em: 15.abr.2017. 